\title{
SOME BIOLOGICAL CHARACTERS OF CHUB MACKEREL (SCOMBER JAPONICUS, HOUTTUYAN, 1782) FROM THE MEDITERRANEAN WATERS OF EGYPT
}

\section{S. I. Rizkalla}

National Institute of Oceanography and Fisheries, Alexamdria, Egypt.

Key words: Biology, Scomber japonicus.

(Received Jan.2,1998)

\section{ABSTRACT}

Zishes of chub-mackerel (Scomber japonicus, Houttuyan, 1782) are mainly $\Gamma$ caught by purse-seine nets using light attraction. The structure of $S$. japonicus catch in the Egyptian Mediterranean waters showed that this species attains ages not exceeding more than four years. Fishes of age group II dominated the catch, whereas those having age groups 0 (juveniles) and I were absent. The length of $S$. japonicus reached $25.9 \mathrm{~cm}$ during its second year of life. This was followed by a slight increase in length during the third and fourth years reaching $29.6 \mathrm{~cm}$ and $32.2 \mathrm{~cm}$ respectively. The back calculated weight for $S$. japonicus showed gradual increase in weight as the fish gets older, where weight at the fourth year $(252.56 \mathrm{~g})$ was nearly twice that obtained during the second year $(133.36 \mathrm{~g})$. The theoretical length $\left(\mathrm{L}_{\infty}\right)$ and weight $\left(\mathrm{W}_{\infty}\right)$ calculated by von Bertalanffy equations were $39.42 \mathrm{~cm}$ and $453.24 \mathrm{~g}$ respectively. The values of condition factor, hepato-somatic and gonado-somatic indices were minimum in August following the end of the spawning season which extends from May to July. The shoals of $S$. japonicus were characterized by lacking immature fishes, so the length and age at the first sexual maturity cannot be determined. The relative fecundity of this species showed that a female produces from 382 to 625 eggs per gram of body weight. 


\section{INTRODUCTION}

Fishes of chub-mackerel (Scomber japonicus, Houttuyan, 1782) are widely distributed in warm and temperate waters (Fischer \& Bianchi, 1984 and Limbong et al., 1988). Hureau and Monod (1979) and Collette and Nauen (1983) pointed out that this species is considered as a primarily coastal pelagic one occurring to about 250 meters depth and is characterized by shoaling in size especially with those of adult fishes. Faltas (1983) mentioned that $S$. japonicus is mainly caught in the Egyptian Mediterranean waters by purse-seine nets using light attraction and found among catches of other pelagic fishes such as jackmackerel, sardines, anchovies, bogues and barracudas.

The purpose of the present study is to throw light on some biological aspects of $S$. japonicus in the Egyptian Mediterranean waters.

\section{MATERIAL AND METHODS}

Samples of Scomber japonicus were randomly collected from purseseine catch of Alexandria fishing center during the period from March to November, 1994. The total length range of 110 specimens varied from 26.0 to $34.0 \mathrm{~cm}$. For each specimen the following information were recorded: date of capture, total length to the nearest $0.1 \mathrm{~cm}$, total and gutted weights to the nearest $0.1 \mathrm{~g}$ and sex. For age determination, the first vertebra was taken, cleaned and examined under binocular microscope at magnification (X10). Distances from the focus of the vertebra to the successive annulii as well as total radius were determined.

Length-weight relationship was determined using the formula of Le Cren (1951) $W=\mathrm{cL}^{\mathrm{n}}$, where $W$ gutted weight in gram and $\mathrm{L}$ total length in $\mathrm{cm}$.

Th theoretical growth was calculated by the von Bertalanffy's growth equations developed by Beverton and Holt $(1957)$ and their parameters $\left(L_{\infty} W_{\infty}\right.$ K \& to) were calculated by Gulland's method (Gulland, 1965). Maximum length $\left(\mathrm{L}_{\max }\right)$ was calculated using the formula: $\left.\mathrm{L}_{\text {mex }}=0.95 \mathrm{~L}_{\infty}\right)$ (Beverton, 1963). 
Some biological chartacers of chub mackerel (Scomber japonicus, Houttuyan, 1782) 103 from the Medkterranean waters of Egypt

Fatness of fish was described by calculating the coefficient of condition (K) from the formula $\mathrm{K}=100 \mathrm{XW} / \mathrm{L}^{3}$ where $\mathrm{W}=$ gutted weight (g) and $\mathrm{L}=$ total length $(\mathrm{cm})$.

Hepato-somatic index was given by using the following formula: HSI $=100 \times W_{i} / W$ where $W_{i}=$ liver weight $(g)$ and $W=$ gutted fish weight $(g)$.

Gonado-somatic index was calculated using the following equation according to Anderson and Gutreuter (1983):

GSI $=100 \mathrm{XW}_{2} / \mathrm{W}$ where $\mathrm{W}_{\mathrm{a}}=$ gonad weight $(\mathrm{g})$ and $\mathrm{W}=$ gutted fish weight (g).

Statistical analyses such as correlation coefficient (r), "t-distribution" test and covariance analysis were applied in the present work according to Snedecor and Cochran (1982).

\section{RESULTS}

\section{Body length-vertebral radius relationship}

The relationship between the radius of the vertebra (R) and total body length (L) was found to be linear (Fig. 1) and expressed by the following equation:

$\mathrm{L}=0.3233+0.0903 \mathrm{R}(\mathrm{N}=70, \mathrm{r}=0.8459)$

By using "t-distribution" test, it was found that the correlation value $(r=0.8459)$ is significant $(\mathrm{P}<0.05)$.

\section{Growth in length}

The back-calculated lengths for $S$. japonicus at different age groups indicate that this species have ages not exceeding more than four years (Table, 1). The catch was characterized by lacking of juveniles and fishes of age group one. The length of $S$. japonicus reached $25.9 \mathrm{~cm}$ during its second year of life. This was followed by slight increase in length during the third and fourth years 
(29.6 and $32.2 \mathrm{~cm}$, respectively).

\section{Length-weight relationship}

The equations of length-weight relationship for both sexes were as follows:

Males: $\log W=-1.7303+2.7310 \log \mathrm{L}(\mathrm{N}=46, \mathrm{~T}=0.9884)$.

Females: $\quad \log W=-2.2443+3.0861 \log L(N=64, r=0.9726)$.

where $\mathrm{W}=$ gutted weight $(\mathrm{g}), \mathrm{L}=$ total length $(\mathrm{cm})$ and $\mathrm{N}=$ number of fish examined.

By using covariance analysis to test the significance between the data of both sexes no significant difference was found ( $F=0.0033, \mathrm{dF}=1,12, \mathrm{P}>0.05$ ). Hence the length-weight data of males and females were pooled and the following equation was given for Combined sexes:

$\log W=-1.9978+2.9175 \log L(N=110, r=0.9853)$.

From Fig. 2, it is shown that the length-weight relationship is curvilinear and the calculated values are found to fit the observed ones.

\section{Growth in weight}

It was found that as a fish gets older, its weight increased markedly. The increase in weight during the fourth year $(252.56 \mathrm{~g})$ was nearly twice than that obtained during the second year of life (133.36 g).

\section{Theoretical growth rate}

The von Bertalanffy's growth formula was used to describe the growth rate of fish. The growth equations obtained for combined sexes were:

$L_{L}=39.42\left[1-\mathrm{e}^{-0.3134(t+1.39)}\right]$
$W_{t}=453.24\left[1-\mathrm{e}^{-0.3182(t+1.44)}\right]^{2.9175}$

The results indicate that the lengths and weights obtained by von Bertalanffy's growth equations nearly coincide with those obtained from the back calculated ones (Table, 1). The estimated length and weight for the missing 
Some biological chartacers of chub mackerel (Bcomber japonicus, Houttuyan, 1782) 105 from the Mediterranean waters of Egypt

age group I which is not represented in the catch are found to be $20.87 \mathrm{~cm}$ and $75.07 \mathrm{~g}$ respectively.

\section{Maximum iength $\left(\mathrm{L}_{\text {max }}\right)$}

Beverton (1963) declared that in nature, the oldest fishes of a stock grow to reach about 0.95 of their asymptotic length. Thus the expected maximum length of $S$. japomicus in the Egyptian Mediterranean waters will be $37.5 \mathrm{~cm}$ while the actual recorded one is $34.0 \mathrm{~cm}$.

\section{Condition factor (K)}

The monthly changes in values of condition factor (Fig. 3) indicate that the maximum values of condition factor for males $(0.78)$ and females $(0.84)$ were observed in November i.e. before the maturation of gonads. Minimum values (males: 0.67 and females: 0.74) were recorded in August at the end of spawning season.

\section{Hepato-somatic inder (HSD)}

Figure. 4 shows monthly changes in the values of hepato-somatic index for both sexes. It is obvious that females had generally higher values than males as they attain their maximum value in April (2.50), while for males their maximum values were observed in November (1.40). The minimum values for both sexes were recorded in August (males:0.34 and females: 0.72 ).

\section{Gonado-somatic index (GSD)}

The minimum values GSI for females and males (Fig. 5) were found during the period from August (female :0.16 and male:<0.01) to November (female : 0.50 and male : 0.07 ), whereas maximum ones were observed in May (female : 8.64 and male : 6.22) and July (female : 4.00 and male : 4.56). A marked drop in the value of GSI was noted in June (female : 2.1 and male : 1.09). It can be concluded that the spawning season of $S$. japonicus extends from May to July and spawning takes place more than once per season. 


\section{Maturity}

As a result of the absence of fishes having lengths less than $26.0 \mathrm{~cm}$ in the catch, so age and length at the first sexual maturity could not be determined and all fishes examined during this work were entirely matured.

\section{Fecundity}

According to Bagenal and Braum (1968), the number of ripe ova in female prior to next spawning period was determined. In twenty ripe females, the absolute fecundity varied from 65,000 to 174,908 eggs for fishes having average length range of $28.3-32.8 \mathrm{~cm}$ with body weights of $170-280 \mathrm{~g}$ i.e. female $S$. japonicus produces from 382 to 625 eggs per gram of body weight.

\section{DISCUSSION}

Scomber japonicus in the Egyptian Mediterranean waters is found in shoals among the catches of purse-seine nets using light attraction. The structure of these shoals showed that this species attained ages not exceeding more than four years and age group II was the dominant one, whereas juveniles and fishes having age group I were completely absent. This result indicates that $S$. japonicus usually shoals by size. Such phenomenon not only characterizes this species in the Mediterranean but also for the same species in the Pacific Ocean (Kramer, 1969).

The present study revealed that growth of $S$. japonicus is very rapid during its second year of life, where its length reaches $25.9 \mathrm{~cm}$. Slight increase was observed in the following successive years reaching $29.6 \mathrm{~cm}$ in the third year and $32.2 \mathrm{~cm}$ in the fourth one. Comparable results were recorded by Lorenzo and Pajuelo (1996) as they noted that the mean length of $S$. japonicus in the Canary Islands during the second, third and fourth years were: $25.9,30.8$ and $34.8 \mathrm{~cm}$, respectively. The present result also agrees with that given by Kramer (1969) as he observed that the growth in length for the Pacific mackerel is very rapid at about two years of age then decreases somewhat in older fishes. 
Some biological chartacers of chub mackerel (Scomber japonicus, Houttuyan, 1782) from the Meriterranean waters of Egypt

In the present work, the length-weight relationship shows nonsignificant difference between the data of both sexes. A similar observation was given for $S$. japonicus in the Canary Islands (Lorenzo and Pajuelo, 1996).

By comparing the value of $L_{\infty}(39.42$ T.L) in the present study with that given in other localities after converting this parameter into forked length using the morphometric equation given by Faltas and Rizkalla (1995), it was found that $\mathrm{L}_{\infty}$ (35.95 F.L) of $S$. japonicus in the present study is relatively less than that given by Ouchi (1978) for the same species in West of Kyushu and East of Tsushima Islands $\left(\mathrm{L}_{\infty}=38.05 \mathrm{~F} . \mathrm{L}\right)$. The maximum length of $S$. japonicus in the Egyptian Mediterranean waters $\left(\mathrm{L}_{\text {max }}: 37.45 \mathrm{~cm}\right.$ ) calculated by Beverton formula (1963) was found to be less than that obtained by Lorenzo and Pajuelo (1996) for the same species in the Canary Islands $\left(L_{\max }: 49.78 \mathrm{~cm}\right)$.

The present results on the gonado-somatic index revealed that the spawning season of Scomber japonicus in the Egyptian Mediterranean waters extends from May to July. The sudden drop in the value of gonado-somatic index in June indicates that this species spawns more than once per season. Such phenomenon agrees with that given by Dickerson et al. (1992) as they noted that females $S$. japonicus of Southern California are characterized by the presence of more than one spawning stage in their ovaries. The spawning period given in the present work coincides with that mentioned in other localities as Muzinic (1981) pointed out that Spanish $S$. japonicus spawns in late spring and summer. Fry (1936), Kramer (1960) and Dickerson et al. (1992) noted that the maximum spawning of $S$. japonicus off Southern California takes place from late April to August with maximum spawning from May to early July. Also in the Southwestern Sea of Japan and East China the spawning season of $S$. japonicus mostly occurs in April (Iizuka and Hamassaki, 1986). The onily exception from the previous studies ones is that given by Habashi and Wojciechowski (1973) and Lorenzo \& Pajuelo (1996) for the same species in the Canary Islands where the spawning period extends from November to March i.e. spawning takes place during winter. 
The present study revealed that it was so difficult to determine the size at the first sexual maturity due to the absence of individuals less than $26.0 \mathrm{~cm}$ length in the catch. Fishes with age group II and successive age groups were found to be mature. This coincides with that given by Kramer (1969) who observed that fishes of age group I do not spawn but most fishes having age group II and older ones spawn. It seems that fishes in the shoal are all mature and that they are undergoing spawning migration.

Study of the condition factor and hepato-somatic index of $S$. japonicus revealed that the higher values of condition factor for both sexes were obtained in November, while higher ones of hepato-somatic index were observed in November and April for males and females respectively (i.e. before the beginning of the spawning period). Minimum values of condition factor and hepatosomatic index for both sexes were observed in August (i.e. at the end of the spawning period). The higher values of hepato-somatic index can be attributed to the physiological changes which take place in the digestive tract resulting in the enlargement of the liver due to the swollen of hepatocytes with glycogen where such changes usually occur during the cyclical periods of starvation, migration or spawning (Ellis et al., 1978). Also Roberts (1978) showed that such increase in the hepato-somatic index may be due to the increase in the activities of the sexual hormones.

As regard to the relative fecundity of $S$. japonicus in the Egyptian Mediterranean waters, it was found that female produces from 382 to 625 eggs per gram of body weight. This number is clearly higher than that given by Mac Gregor (1976) for the Pacific mackerel (284 eggs/g) and Pena et al. (1986) for the Peruvian S. japonicus (278 eggs/g).

\section{REFERENCES}

Anderson, R. O. and Gutreuter, S. J. (1983). Length, weight, and associated structural indicies. In: Fisheries Techniques. Nielsen, L. A. and Johnson, D. L. (eds.) 283-300. Bethesda; American, Fish. Soc. 
Some biological chartacers of chub mackerel (Scomber japonicus, Houttuyan, 1782) 109 from the Mediterranean waters of Egypt

Bagenal, T. and Braum, E. (1968). Eggs and early life history. In: W. E. Ricker (Editor), Methods for Assessment of Fish Production in Fresh water 159-178. Black well, Oxford.

Beverton, R. J. H. (1963). Maturation, growth and mortality of Clupeid and Engraulid stocks in relation to fishing. Rapp. P-V. Réun CIEM, (154): 44-67.

Beverton, R. J. H. and Holt, S. J. (1957). On dynamics of exploited fish populations. Fish Invest., London Ser. 2(19), $533 \mathrm{pp}$.

Collette, B. B. and Nauen, C. E. (1983). Scombrids of the world. FAO Fish., Synop., 2(125): 55-59.

Dickerson, T., Macewicz, B. J. and Rose Hunter, J. (1992). Spawning frequency and batch fecundity of chub-mackerel, Scomber japonicus during 1985. CalCOFI Rep., (33): 130-140.

Ellis, A. E; Roberts, R. J. and Tytler, P. (1978). The anatomy and physiology of teleosts [In: Fish Pathology, Roberts, R. J. (ed.) 13-54]. Bailliere Tindall, London.

Faltas, S. N. (1983). Study of purse-seine fisheries in Egyptian Mediterranean waters with special reference to the biology of sardine in the catch. $M$. Sc. Thesis, Fac. Sci., Alex. Univ. 194 pp.

Faltas, S. N. and Rizkalla, S. I. (1995). Biometeric comparison of chub mackerel (Scomber japonicus Houttuyan, 1782) from the Mediterranean and Red Sea, Egypt Bull. Nat. Inst. Oceanogr. \& Fish. A.RE. 2:(21). 439-449.

Fischer, W. and Bianchi, G. (1984). FAO species identification sheets for fishery purposes. Western Indian Ocean (Fishing Area 51). Rome, FAO 4. 
Fry, D. H. JR (1936). A preliminary summary of the life history of the Pacific mackerel (Pneunatophorus diego). Calif. Fish Game, 22: 30-39.

Gulland, J. A. (1965). Manual of Methods for Fish Stock Assessment. Part 1. Fish Population Analysis. FAO Fish. Techn. Rep. 40 (Revision): 68 pp.

Habashi, B. and Wojciechowski, J. (1973). Observation on the biology of Scomber japonicus off North west Africa. ICES Doc. C. M. 1973/J : 20; 9 pp. (mimeo).

Hureau, J. C. and Monod, Th. (1979). Checklist of fishes of the northeastern Atlantic and the Mediterranean. UNESCO, Fontenoy, 75700 Paris, Univ. France Vendôme, Clofnam (1): 465-466.

Iizuka, K. and Hamasaki, S. (1986). Ecology of common mackerel in the south-western Sea of Japan and East China Sea-II. Biological characteristics in each fishing ground. Bull. Seikai Reg. Fish. Res. Lab. (63): 15-48.

Kramer, D. (1960). Development of eggs and larvae of Pacific mackerel and distribution and abundance of larvae 1952-56. U.S. Fish Wildl. Ser. Fish. Bull. 60 (174): 393-438.

Kramer, D. (1969). Synopsis of the biological data on the Pacific mackerel, Scomber japonicus, Houttuyan (North-east Pacific). U.S. Fish Wildl. Ser. Cir. 302, FAO, Fish. Synop. 40: 18.

Le Cren, E. D. (1951). The length-weight relationship and seasonal cycle in gonad weight and condition in the perch (Perca fliviaitilis). J. Anim. Ecol., 20 (2): 201-219.

Limbong, D.; Hayashi, K. and Matsumiya, Y. (1988). Length-cohort analysis of common mackerel Scomber japonicus, Tsushima warm current stock. Bull. Seikai Reg. Fish. Res. Lab. 66: 119-129. 
Lorenzo, J. M. and Pajuelo, J. G. (1996). Growth and reproductive biology of chub-mackerel Scomber japonicus off the Canary Islands. S. Afr. J. Mar. Sci. $17: 275-280$.

Mac Gregor, J. S. (1976). Ovarian development and fecundity of five species of California current fishes-Calif. Coop. Oceanic Fish. Invest. Rep. 18: 181-188.

Muzinic, R (1981). Summary of present knowledge of the Spanish mackerel (Scomber japonicus Houtt.) in the Adriatic. Rapp. comm. int. Mer. Medit., 27(5): 95-96.

Ouchi, A. (1978). Studies on the age and growth of common mackerel Scomber japonicus, in the waters West of Kyushu and East of Tsushima Islands. Bull. Seikai Reg. Fish. Res. Lab. (51): 97-98.

Pena, N.; Alheit, J. and Nakama, M. E. (1986). Fecundidad parcial de la Caballa del Peru (Scomber japonicus Peruanus). Inst. del Mar del Peru. Boletin, 10(4): 91-104.

Roberts, R. J. (1978). The pathophysiology of Teleos t [In: Fish Pathology. Roberts, R. J. (ed.): 55-91] Bailliere Tindall London.

Snedecor, G. W. and Cochran, W. G. (1982). Statistical Methods. The Iowa State Univ., Seventh ed.: 507 pp. 

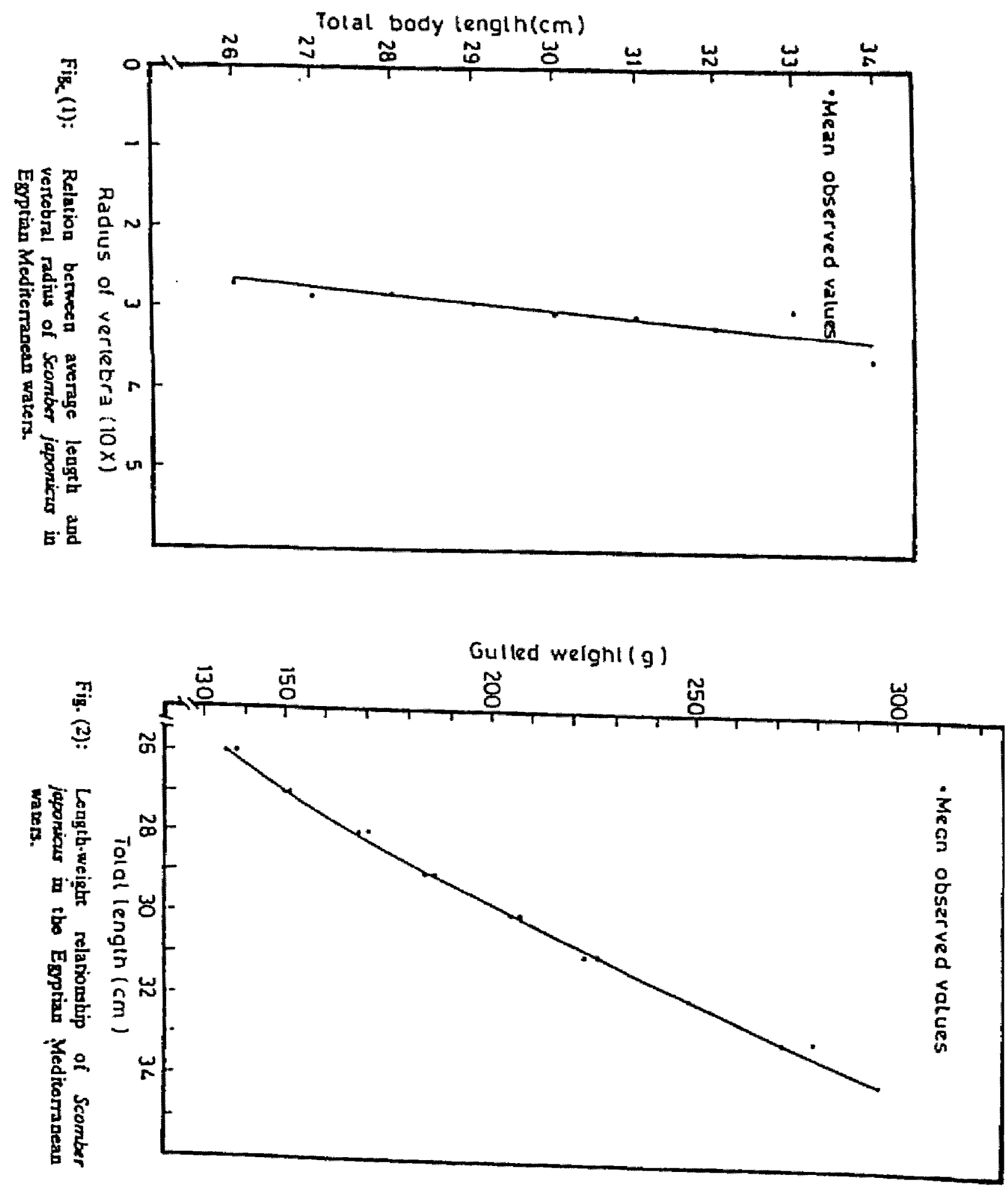

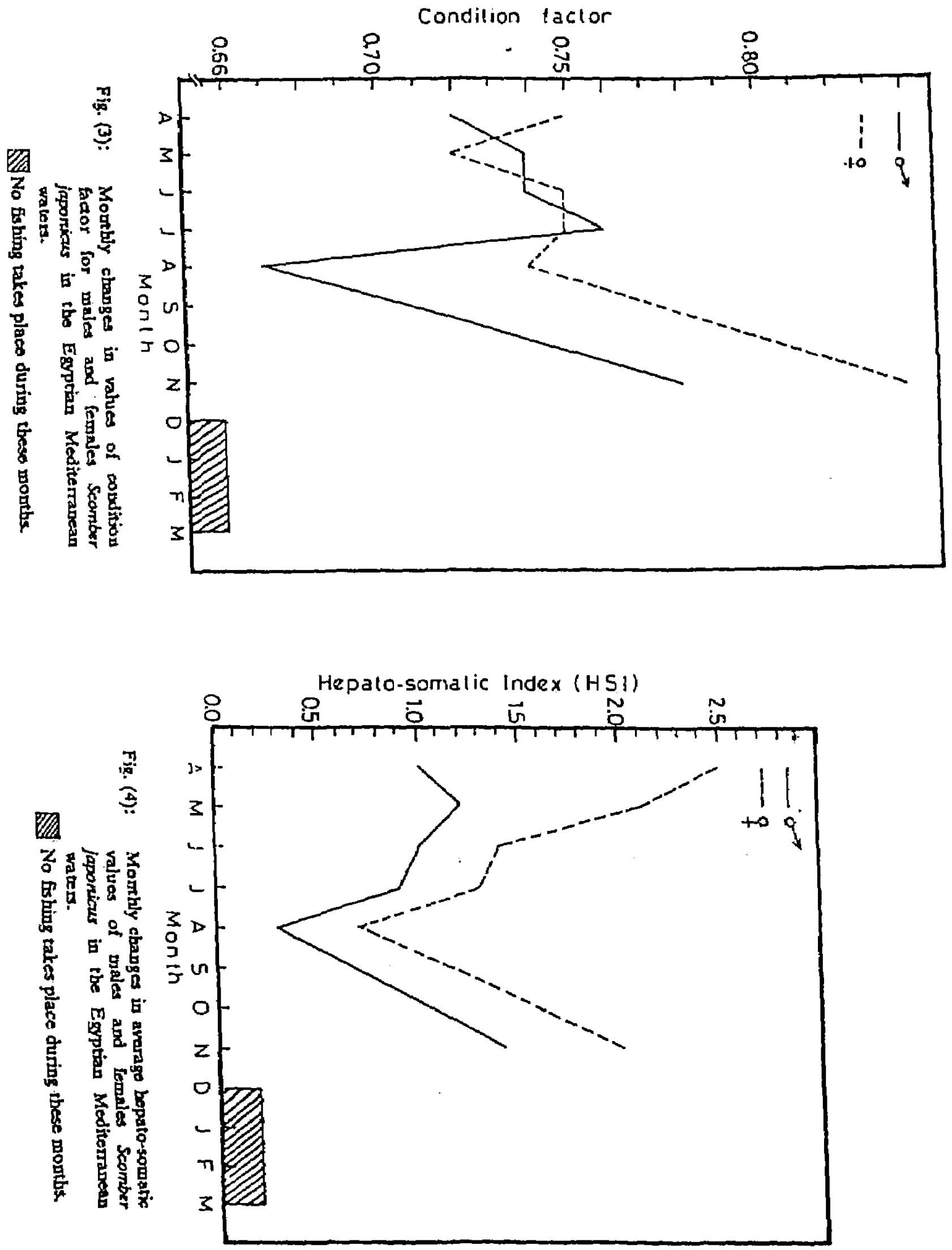


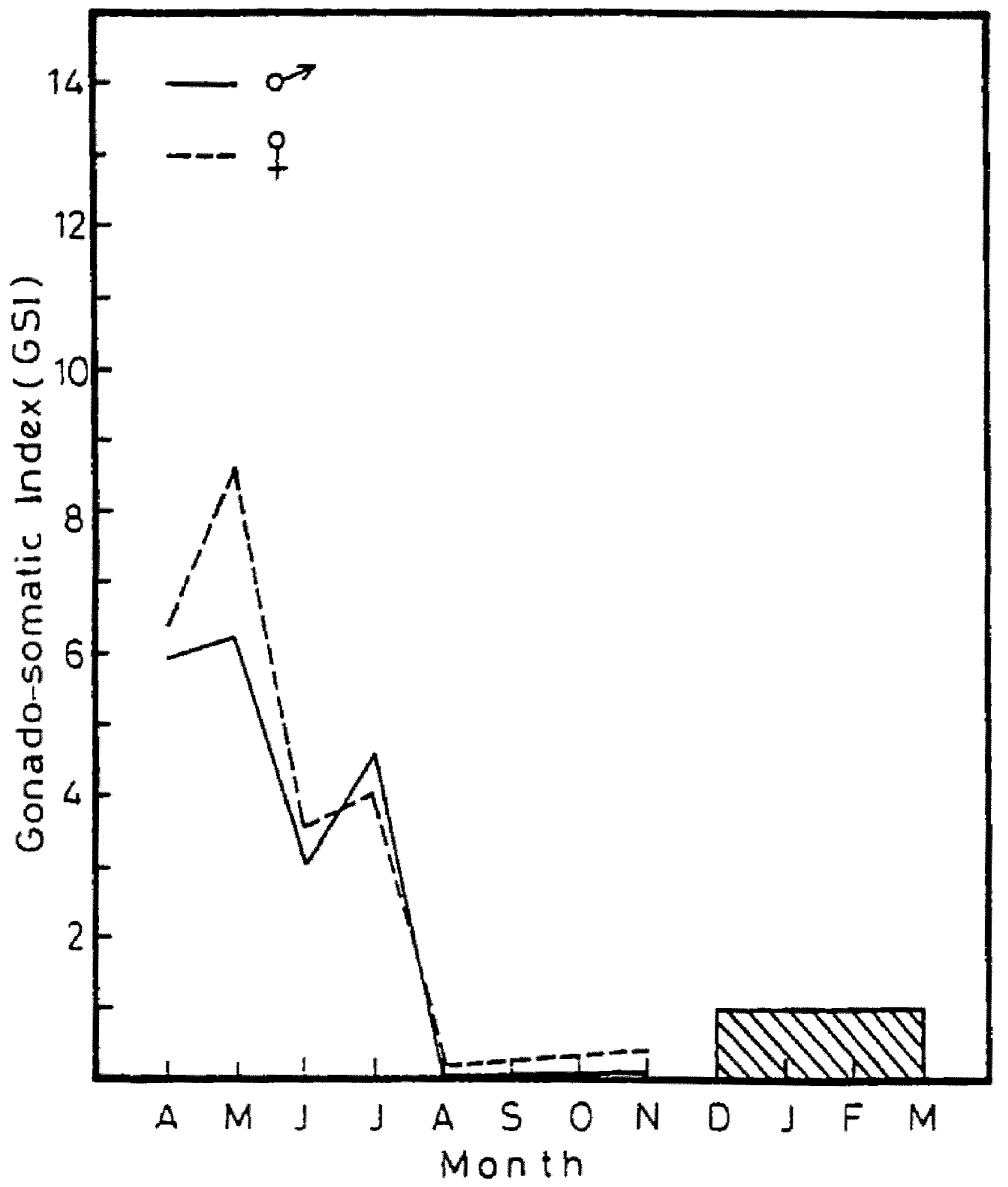

Fig. (5): Monthly changes in average gonado-somatic values of males and females Scomber japonicus in the Egyptian Mediterramean waters.

MV tishing takes place during these months. 
Table (1): Back-calculated lengths ( $\mathrm{cm}$ ) and weights (g) at different ages and those predicted by von Bertalanffy ( $v$. B) equations for combined sexes of Scomber japonicus in the Egyptian Mediterranean waters.

\begin{tabular}{||l|c|c|c|c||}
\hline \multicolumn{1}{|c|}{ Item } & \multicolumn{4}{c|}{ Age (year) } \\
\cline { 2 - 5 } & 1 & 2 & 3 & 4 \\
\hline Number of fish & $*$ & 52 & 15 & 3 \\
Mean length at capture (cm) & $*$ & 26.24 & 30.36 & 32.50 \\
Back-calculated length (cm) & $*$ & 25.89 & 29.55 & 32.22 \\
Lengths predicted from v. B (cm) & 20.87 & 25.89 & 29.55 & 32.22 \\
Back-calculated weights (g) & $*$ & 133.36 & 196.13 & 252.56 \\
Weights predicted from v. B (g) & 75.07 & 138.05 & 200.83 & 256.65 \\
\hline
\end{tabular}

* Not included in the catch. 


\title{
دراسة بعض الصقات اليرلوجية لأبماك السكرمبر في المياه المصريه للبحر المترسط
}

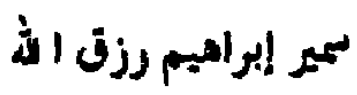

المهلد القومى لعلوم البحار والمعهايل ردواله

يتم مبد أمعاك السكرمبر نى المياه المصريه للبحر المتوسط بأستخدلم شباك الشانشولا والضوء الصناعى الذىى يعمل على هذب تلك الالكماك.

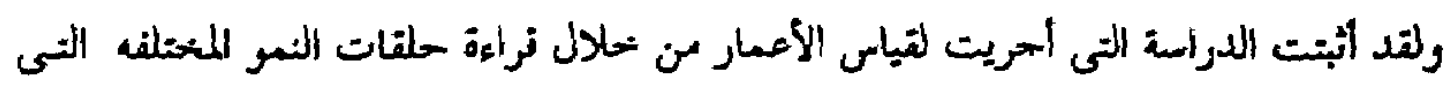

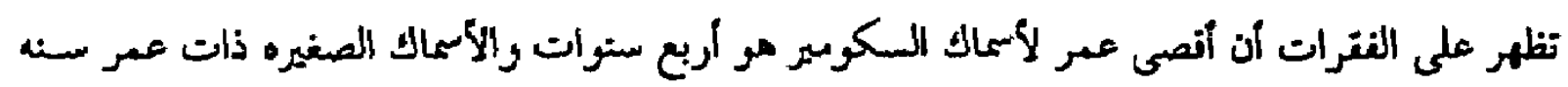

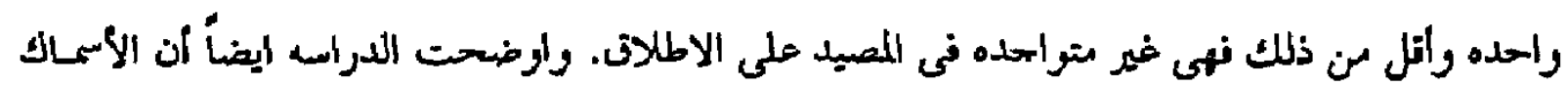

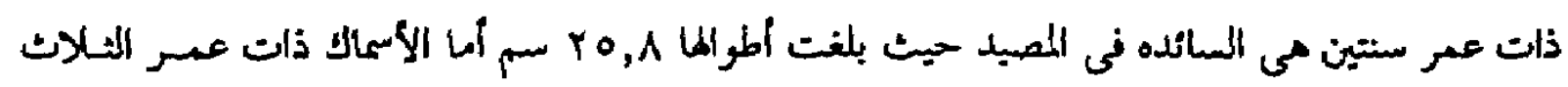

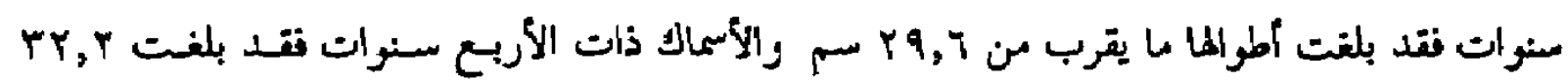

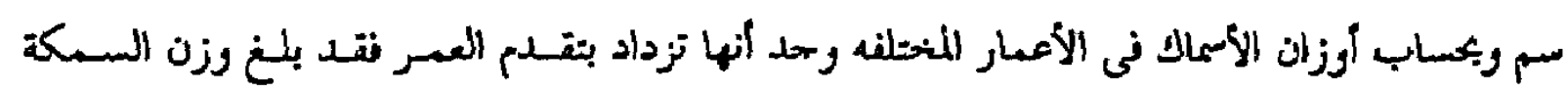

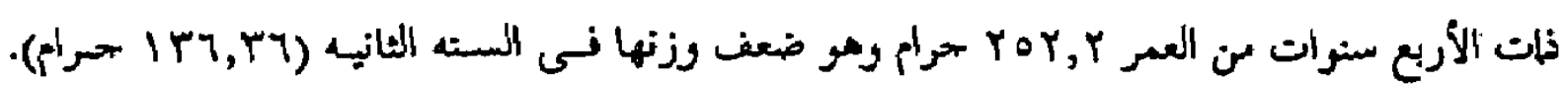

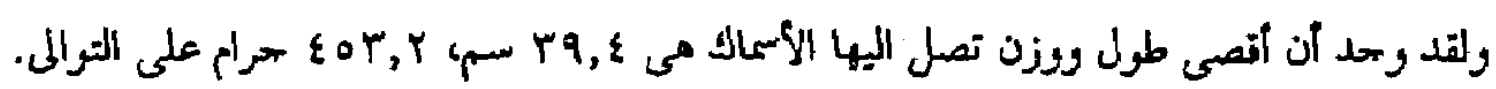

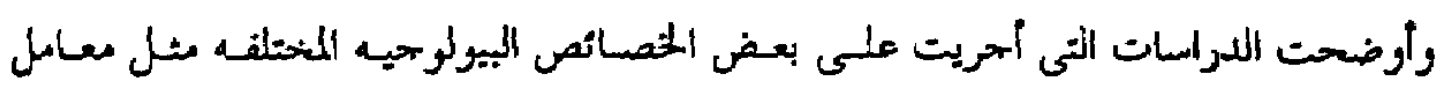

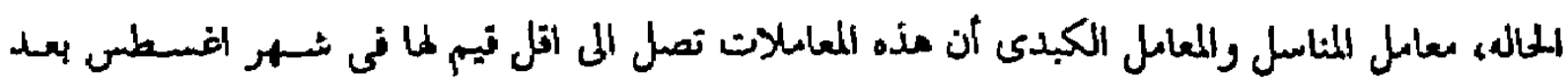

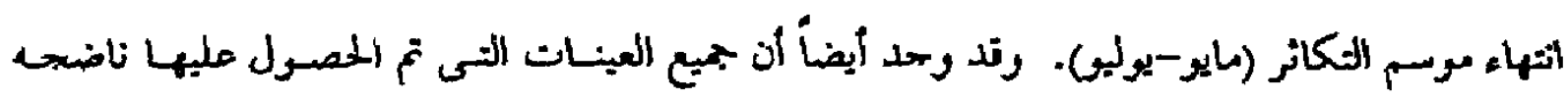

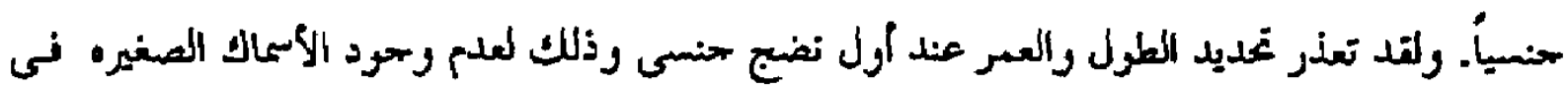
اللميد.

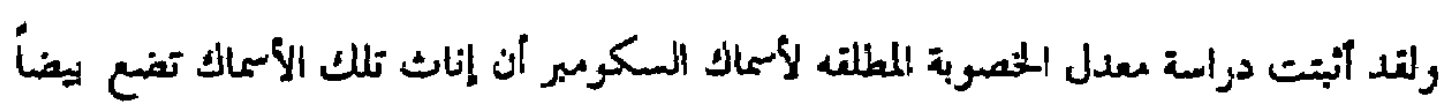

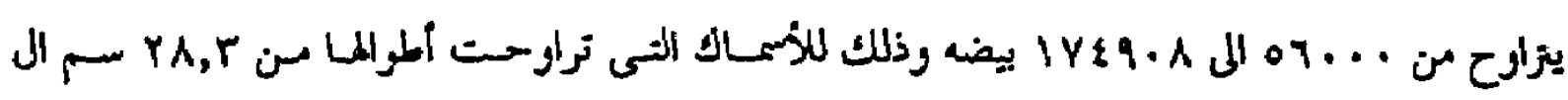

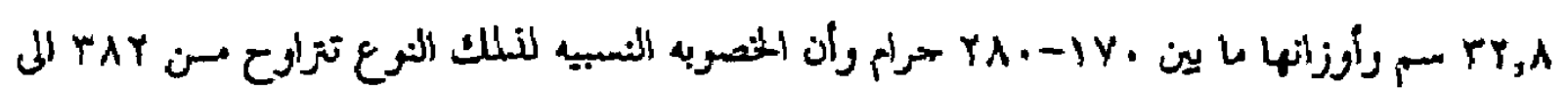
مrا بيضه لكل حرام من وزن السمكه. 